\title{
The culture of market oriented organisations
}

Citation for published version (APA):

Kasper, J. D. P. (2005). The culture of market oriented organisations. METEOR, Maastricht University School of Business and Economics. METEOR Research Memorandum No. 052 https://doi.org/10.26481/umamet.2005052

Document status and date:

Published: 01/01/2005

DOI:

10.26481/umamet.2005052

Document Version:

Publisher's PDF, also known as Version of record

\section{Please check the document version of this publication:}

- A submitted manuscript is the version of the article upon submission and before peer-review. There can be important differences between the submitted version and the official published version of record.

People interested in the research are advised to contact the author for the final version of the publication, or visit the DOI to the publisher's website.

- The final author version and the galley proof are versions of the publication after peer review.

- The final published version features the final layout of the paper including the volume, issue and page numbers.

Link to publication

\footnotetext{
General rights rights.

- You may freely distribute the URL identifying the publication in the public portal. please follow below link for the End User Agreement:

www.umlib.nl/taverne-license

Take down policy

If you believe that this document breaches copyright please contact us at:

repository@maastrichtuniversity.nl

providing details and we will investigate your claim.
}

Copyright and moral rights for the publications made accessible in the public portal are retained by the authors and/or other copyright owners and it is a condition of accessing publications that users recognise and abide by the legal requirements associated with these

- Users may download and print one copy of any publication from the public portal for the purpose of private study or research.

- You may not further distribute the material or use it for any profit-making activity or commercial gain

If the publication is distributed under the terms of Article $25 \mathrm{fa}$ of the Dutch Copyright Act, indicated by the "Taverne" license above, 


\title{
The culture of market oriented organisations
}

\author{
Hans Kasper \\ Professor of Services and Retail Management \\ Maastricht University, and \\ Director of Etil bv, Maastricht, the Netherlands
}

December 6, 2005

Special thanks to Sheelagh Matear (Lincoln University, New Zealand) and Rob Aitken (University of Otago, New Zealand) who gave me valuable suggestions to improve this paper during my stay as visiting professor at the University of Otago. 


\title{
The culture of market oriented organisations
}

\begin{abstract}
This paper investigates the relationship between corporate culture and market orientation using a different methodology to those usually found done in empirical studies on this topic. ${ }^{1}$ Conventionally, one or two key informants provide information on the firm's marketing practices in large scale quantitative cross-sectional studies; these few respondents provide their opinion on the firm's actual marketing practices which are then considered as a reliable representation of both the (whole) firm's culture and its market orientation.

We have taken a different approach. Firstly, we chose to do multiple case studies in stead of cross sectional research. These case studies were small scale and qualitative; next a large(r) scale quantitative study was done within those organisations. Secondly, all employees in an organisation were invited to participate in the study: only then is it possible to measure culture as the shared beliefs in the company. Corporate culture itself as well as the marketing practices have been investigated as two separate constructs in our case studies. Both are measured via employee perceptions. Thirdly, we are looking at the possible configuration of market orientation and corporate culture.
\end{abstract}

Almost all of the propositions generated are supported. The degree of openness appeared to be crucial to an organisation's market orientation. Moreover, such a culture is also resultsoriented, employee-oriented and professional. It also has a balanced position on the two other dimensions: pragmatic/normative and loose/tight control. From the marketing perspective, the essential building blocks of a market oriented culture include: the internal cooperation, internal communication, drive to be the best, lack of pursuing self interest, learning from mistakes and from experiences in the market place, clarity about customer needs and better relative quality than competitors'.

Because market orientation and corporate culture were measured as two distinct constructs, this study offers new insights in both domains as to what organisations should change to be(come) market oriented.

\footnotetext{
${ }^{1}$ We will use the terms corporate culture and organisational culture as synonyms in this paper. In the empirical part of this study profit as well as not for profit organisations have been investigated.
} 


\section{The culture of market oriented organisations}

\section{Introduction}

Research and thinking in the domain of market orientation started in the 1980s of the last century. ${ }^{2}$ Much work in this area has been inspired by the popular writings of Peters and Waterman (1982) and Deal and Kennedy (1982). These authors emphasise the importance of a customer orientation or customer oriented culture. Moreover, they hold that such a culture to the company's strategy should be properly matched. Quite a few scholars have pinpointed the general notion of a proper fit between corporate strategy and corporate culture (e.g. Tichy, 1982; Fombrun, 1983; Fombrun, 1984).

So, we may conclude there should be a proper match between corporate culture, market orientation, corporate strategy and marketing strategy. However, until today, it is not completely clear what culture, what market orientation and what strategy fit or not. Some insights into this relationship do exist. However, a full and detailed understanding is still lacking. This paper will provide more insight in that topic.

In this paper, we will elaborate on some of the possible links between corporate culture and market orientation to investigate which configurations between market orientation and corporate culture exist. The goal of our research is to find, in an exploratory way, what links exist between the cultural variables and the marketing variables specific to market oriented organisations. In fact it is aimed at finding relationships between the variables which encourage or block the market oriented culture of an organisation. ${ }^{3}$

\section{Generic strategies and market orientation}

After the popular writings, the fundamental work on market orientation started with the publications by Narver and Slater (1990) and Kohli and Jaworski (1990). They developed the concepts that have been very influential in this area of research. There are a few results from empirical studies that shed some light on the relationship between strategy and market orientation. Narver and Slater (1990) showed that the correlation between market orientation and a differentiation strategy was much higher than the correlation between market orientation and a low cost strategy in their empirical study in a US manufacturing company. Alternatively, these results imply that market orientation is better suited to a generic strategy of differentiation (which closely resembles the marketing concept) than a low cost strategy (which relates very much to high volumes, large batches of one type of product); on the other hand, they imply that market orientation is not an exclusive feature of one of the two generic strategies. Day (1990) integrated Michael Porter's three generic strategies and his own view on market orientation. He holds that market orientation is a combination of a customer orientation (which typically comes to the fore in a differentiation or focus strategy) and a competitor orientation (which typically comes to the fore in a low cost orientation i.e. being cheaper and providing better value for money). In other words, it would be typical for a market oriented firm to define a specific market segment, target group of customers or even

\footnotetext{
${ }^{2}$ It first started with issues about customer orientation, later on it was broadened to market orientation. At first the concept has been called customer orientation or customer driven. Later on, terms like market orientation, market driven and market driving have been introduced (see e.g. Kumar, Scheer and Kotler, 2000). We will not go into the debate about the - possible - differences between the latter three and use the term market orientation generically (see also Day, 1999).

${ }^{3}$ The issue of what kinds of strategies organisations follow has been left out of our study. In the qualitative studies preceding the actual field work, we encountered many organisations having difficulties in clearly indicating what kind of strategy they follow once they have to choose between the strategies belonging to the well-known typology of generic strategies as developed by Porter, the four strategies being part of the Miles and Snow typology or the four marketing strategies as developed by Kotler. Since it was our aim to investigate market orientation and corporate culture, we did not want to develop a new questionnaire to measure corporate or marketing strategy. Moreover, we were concerned to assume that the questionnaire should not be too long.
} 
one customer and respond to their needs with the lowest cost possible; to be cheaper, better, faster, providing more value than a competitor. This way of reasoning thus combines two approaches, namely responding to well known customer needs and keeping cost as low as possible. Matsuno and Mentzer (2000) found some effects of the strategy type a firm has chosen in answering the question "what strategy type will benefit the most from becoming more market oriented?" They applied the Miles and Snow typology of the prospectors, analysers, defenders and reactors to this relationship. Their study among manufacturers in the US reveals differences in this effect for prospectors (usually characterised as innovators in markets and products), defenders (are supposed to excel in efficiency and have narrow product market domains) and analysers (who aspire to be the best in all performance dimensions as a combination of the strengths of defenders and prospectors). It appeared that "Prospectors would benefit the greatest gain, over both analyzers and defenders, in market share, sales growth, and percentage of new product sales by increasing market orientation level." but also that "... there is no direct path from the strategy type to a market orientation." (Matsuno and Mentzer, 2000, pp. 10 - 11) However, this does not mean that there could be no mediating factor in the relationship between strategy type and market orientation. "For example, strategy type may determine a type of corporate culture, which in turn may influence the level of market orientation. More research on the relationships among these three related but distinct constructs and establishment of the relevant culture dimensions to the scale are warranted."(Matsuno and Mentzer, 2000). In sum, there is no clear proof yet on the relationship between market orientation and generic strategies.

\section{Innovation, learning organisation and market orientation}

Since the early nineties, more attention has been paid to the relationship between (product) innovation and market orientation. Typically, the concept of organisational learning has also been introduced in those studies. ${ }^{4}$ In that respect, Slater (2001) concluded that until now market orientation has been focussing more on incremental learning than on break through learning.

Deshpandé, Farley and Webster (1993, p. 31) report on their Japanese study that customeroriented and innovative firms do perform better. The authors speculate that the leaders are firms that are first to market their products and services and are also at the cutting edge of technological innovation. Hurley and Hult (1996) provide a valuable overview of the findings in studies on the relationships between market orientation and innovation. They state, amongst others, that (p.45) "A market- and learning oriented culture, along with other factors, promotes a receptivity to new ideas and innovation as part of an organization's culture (innovativeness). Innovativeness in an organization's culture, when adequate resources are present, facilitates the implementation of innovations (innovative capacity)." Their empirical study was conducted in a large agency of the US Federal government. Therefore, hardly any attention has been paid to market orientation in that part of the study. One of their final conclusions is that higher levels of innovativeness are associated with cultures that emphasize learning, development, and participative decision making. Han, Kim and Srivastava (1998) conducted a study to investigate to what extent organisational innovativeness affects the market orientation - corporate performance relationship. The study was done in the US banking industry. Organisational innovations consist of technical innovations and administrative innovations in this study. The Narver and Slater approach to market orientation (customer orientation, competitor orientation and interfunctional coordination) has been used. In general, the results suggest that "...market orientation facilitates an organization's innovativeness, which, in turn, positively influences its business performance." and "....all three components of market orientation are conducive to facilitating both technical and administrative innovations when the level of technological turbulence in the business environment is relatively high.”(p. 40) So, a market oriented

\footnotetext{
${ }^{4}$ There are also a few studies on market orientation and organisational learning in general; see for instance Slater and Narver, 1995; and Baker and Sinkula, 1999.
} 
culture will facilitate organisational innovativeness. In line with this conclusion, Baker and Sinkula (1999, p. 411) showed “... that a firm's learning orientation is likely to indirectly affect organizational performance by improving the quality of its market-oriented behaviors and directly influence organizational performance by facilitating the type of generative learning that leads to innovations in products, procedures, and systems." Lukas and Ferrell (2000) also used the Narver and Slater three component scale of market orientation to investigate the relationship between three kinds of product innovation: line extensions, metoo products, and, new-to-the-world products. The study was developed on the basis of a sample of US manufacturing companies. They concluded “... that product innovation varies with market orientation. Specifically, (1) customer orientation increases the introduction of new-to-the-world products and reduces the launching of me-too products, (2) competitor orientation increases the introduction of me-too products and reduces the launching of line extensions and new-to-the-world products, and (3) interfunctional coordination increases the launching of line extensions and reduces the introduction of me-too products (Lukas and Ferrell, 2000)."

It has been discussed whether innovation is a mediator or has a mediating effect in the market orientation - performance relationship. ${ }^{5}$ Matear et al. (2002, p. 1070) conclude that “ ... market orientation both has a direct contribution to performance and also contributes through innovation, with innovation mediating the contribution." and conclude that their results "... support a contributory relationship between market orientation and innovation." It became also clear that market orientation is not the only source of competitive advantage.

It seems probable that corporate culture is reflected in an organisation's market orientation which sets the framework for formulating and implementing its strategy and actions as shown in Figure $1 .{ }^{6}$

\section{Figure 1 The basic model}

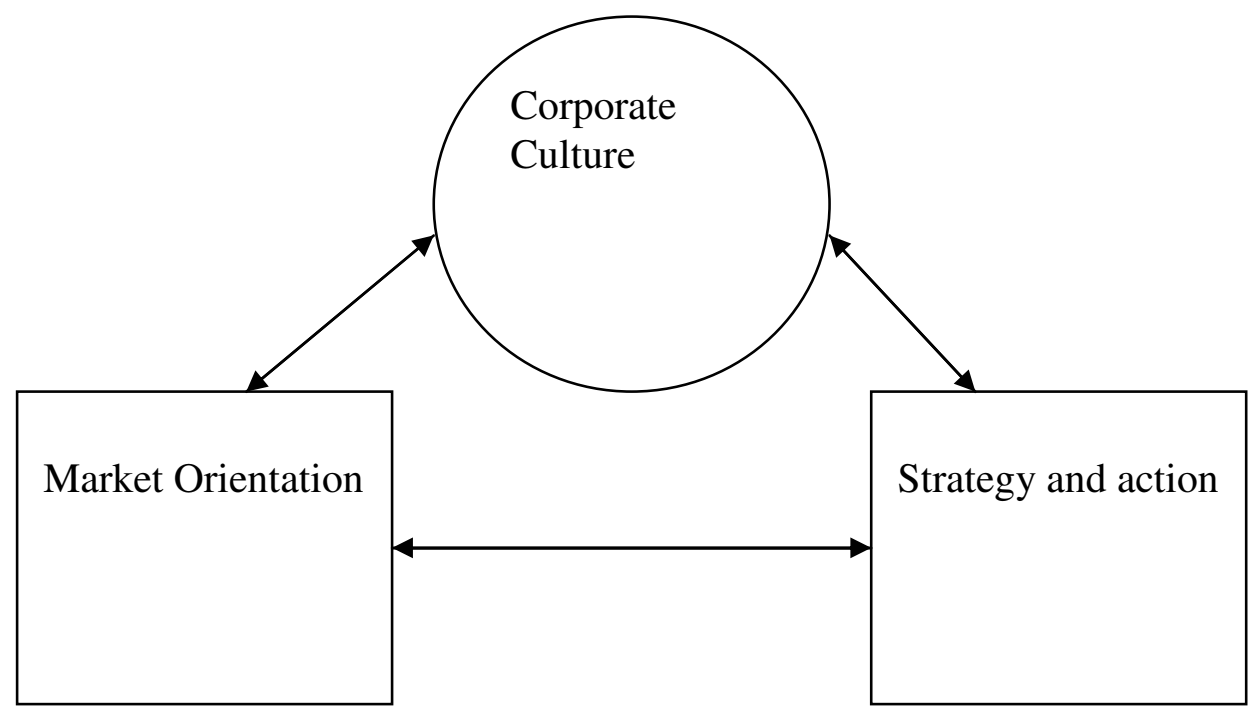

Both culture and strategy mutually affect one another implying specific configurations of culture, market orientation and marketing strategy and actions will exist. These

\footnotetext{
${ }^{5}$ For an overview, see Matear, Osborne, Garrett and Gray, 2002.

${ }^{6}$ Since all these concepts are closely related to one another, it will be difficult to hypothesize ex ante which factor determines which factor in a causal way. Also, in empirical studies, it will be difficult to prove that causality. Analysing possible configurations of corporate culture, market orientation and strategy/actions is then a well established alternative approach. We have to follow that methodological route since the number of case studies is limited to 36 . This will be elaborated upon the following section.
} 
configurations may - in turn - be determined by specific contingencies (Miller and Mintzberg 1983; Miller 1986; Day, 1999). ${ }^{7}$

In sum, the exact configuration of market orientation, strategy and culture has not yet been found. If such insight can be found, it will become clearer what organisations should do to transform from a sales or production orientation to a market orientation, and consequently improve performance. That information will support the change management processes that will have to take place.

Therefore, we will focus on the cultural perspective on market orientation as it is the fundamental, underlying factor determining how the organisation looks at the market and determines how it wants to act and position itself in the market. ${ }^{8}$

\section{Our perspective on market orientation}

Much has been said in the past twenty years about the need to be market oriented. But why? The basic premise is that market oriented firms perform better than firms that are not (or less) market oriented (see also Hooley, Saunders and Piercy, 1998). Or, as Day has pointed out (1999, p. ix): "Our answer is that in an era of increasing market turbulence and intensifying competition, a robust market orientation has become a strategic necessity. Only with superior skills in understanding, attracting and keeping customers can firms devise strategies that will deliver superior customer value and keep this strategy aligned with changing market requirements."

The basic premises just formulated have been confirmed in many empirical studies. ${ }^{9}$ In their meta-analysis of the many articles investigating the relationship between market orientation and business performance, Rodriguez Cano, Carillat and Jaramillo (2004) concluded that this relationship is positive and consistent worldwide. Stronger relationships were found for not for profit organisations than for profit firms as well as for service providers than manufacturers.

The cultural perspective of market orientation will determine the approach that has been taken in this paper. That cultural perspective will also be regarded as the starting point for the managerial implications of being or becoming market oriented. An organisation takes a particular position on a scale ranging from being truly market oriented to not being market oriented at all. So, it is not a matter of being market oriented or not, but the degree of market orientation that is crucial. Our definition of market orientation is:

"the degree to which an organisation in all its thinking and acting (internally as well as externally) is guided by and committed to the factors determining the market behaviour of the organisation itself and its customers". ${ }^{10}$

\footnotetext{
${ }^{7}$ The existing literature on market orientation has already revealed that many factors may moderate or mediate the relationship between market orientation and performance. Market turbulence, technological change, innovation, customer power, market growth or competitor hostility have been mentioned in that respect. The most relevant ones for our research have been discussed in this paper.

${ }^{8}$ So we will not focus on one of the other four perspectives on market orientation that Lafferty and Hult (2001) mention in their overview article: the decision-making perspective, the market intelligence perspective, the strategic perspective and the customer perspective. We focus on the fifth perspective they mention: the culturally based behavioural perspective.

${ }^{9}$ Although some studies do not confirm this relationship (e.g. Han, Kim and Srivastava, 1998; Sargeant and Mohamad, 1999; Caruana, Pitt and Berthon, 1998), the vast majority of the studies do. Hart and Diamantoploulos (1993) found a weak positive relationship, whereas Greenley (1995) found no association at all.

${ }^{10}$ This definition, and its operationalisation, is not only based on the work done by Narver and Slater (1990) and Kohli and Jaworski (1990) on market orientation or the popular writings on it by Deal and Kennedy (1982) or Peters and Waterman (1982). It has a broader background since market orientation relates to the basics of the firm and how the many stakeholders of the firm perceive them (see the section on methodology).
} 


\section{Market orientation as a source of competitive advantage}

Being market oriented is one of the internal strengths that is hard to imitate, difficult to sustain, not transparent nor transferable (see also Grant 1991). Market orientation can be regarded as one of the resources giving the firm a competitive advantage (Hunt and Morgan, 1995; Hunt and Morgan 1996; Hunt, 2001). Day $(1994,1999)$ mentions in this respect the capabilities of market driven organisations: market sensing, market relating and strategic thinking.

Sensing that the market required an open mind to new information about trends in the market, Day (1999) suggested a number of devices that can be used to accomplish this:

- $\quad$ creating a spirit of open-mind inquiry;

- $\quad$ carefully analyzing rivals' actions;

- $\quad$ listening to staff on the front lines;

- $\quad$ seeking out latent needs;

- $\quad$ active scanning of the periphery of the market;

- $\quad$ encouraging continuous experimentation" (to get better insight in market trends).

The market driven organisation has increased capability for creating and maintaining relationships with customers: the market relating capability. Such a relationship orientation pervades all parts of the organisation's mind set, values and norms. It sets the standard for all interactions with the customer during the process of buying, using and disposing of the product. So, the environmental impact of the product or service can also be taken into account. Information technology eases the creation of the knowledge base necessary to implement the relationship orientation. HRM plays a crucial role here as well, since it is important to keep employees on board who know the customer. Employee loyalty and customer loyalty go hand in hand according to the concept of the Service Profit Chain (Heskett, Sasser and Schlesinger, 1997).

The capability of strategic thinking implies that all "... functions and attributes are aligned around a clear-cut value proposition that does not try to be all things to all people." (Day, 1999, p. 223). ${ }^{11}$ Further, the "... most successful market-driven change initiatives were designed to meet six conditions:

$$
\begin{aligned}
& \text { - } \quad \text { demonstrate leadership commitment; } \\
& \text { - } \quad \text { mobilize commitment at all levels; } \\
& \text { - } \quad \text { shape the vision; } \\
& \text { - } \quad \text { align structures, systems and incentives; and } \\
& \text { sustain the change." (Day, 1999, p. 225.) }
\end{aligned}
$$

Harris and Ogbonna (2001) investigated the relationship between leadership style and market orientation empirically. They started this study because they hold (p. 748) “... that existing studies overlook or ignore the potential impact of leadership style on market orientation." Leadership styles may block or encourage the development and implementation of a company's market orientation. Harris and Ogbonna (2001) used the Narver and Slater three component model of market orientation and three types of leadership: participative, supportive and instrumental. The empirical study consisted of a multi-industry sample including private and public limited UK companies. The styles of participative and supportive leadership are all positively associated with the overall market orientation and with its three components: customer orientation, competitor orientation and interfunctional coordination. Contrary to these results, instrumental leadership is negatively associated with overall market orientation and with each of the three components. They also found (p.756) that "... over $27 \%$ of the variation of the measure of overall market orientation around its mean can be attributed to varying leadership styles, indicating that leadership style is a key

\footnotetext{
${ }^{11}$ This statement about 'not being everything to all people' is also the underlying notion for Treacy and Wiersema (1995) to develop their three value disciplines: customer intimacy, product quality and operational excellence.
} 
antecedent to market orientation." MacKenzie et al. (2001, p. 115) have shown, in a case study of a US insurance company in the US, that not only "... transformational leadership influences salespeople to perform 'above and beyond the call of duty' but also that transformational leader behaviors actually have stronger direct and indirect relationships with sales performance and organizational citizenship behavior than transactional leader behaviors." So, transformational styles of leadership are to be preferred in market oriented organisations to instrumental styles.

Hooley, Greenley, Fahy and Cadogan (2001) distinguish between the marketing assets (= resource endowments the firm has acquired or built over time and that can be deployed to advantage in the market place) and the marketing capabilities (= the glue that binds the assets together and facilitates their effective deployment in the market place). Marketing assets can be

- $\quad$ customer based (e.g. company name and reputation, branding, market knowledge, customer relationships, customer data bases);

- $\quad$ distribution or supply chain based (e.g. distribution network, relationships with key suppliers);

- $\quad$ internal based (e.g. cost advantages, information systems, technological skills, legal patents and copyrights, licences and franchises); and

- $\quad$ alliance based (e.g. alliances giving access to new markets, new technologies or new managerial resources).

Marketing capabilities may be

- $\quad$ outside-in capabilities (e.g. Day's market sensing, market research, market bonding, for instance via customer relationship management programs);

- $\quad$ inside-out capabilities (e.g. financial management, cost control, technology development and integrated logistics);

- $\quad$ spanning capabilities integrating the inside-out and outside-in capabilities (e.g. customer order fulfilment, pricing, purchasing, customer service delivery and new product development or new service development); and

- $\quad$ networking capabilities (e.g. managing relationships with suppliers, pooling expertise with strategic partners, sharing mutual trust and commitment with strategic partners). ${ }^{12}$

All these resources, assets, capabilities, leadership styles and conditions are clearly linked to the underlying values of the company: its culture. They can be considered as issues stemming from the openness of the company's culture like the external orientation toward the market, the clarity in vision, strategy and structure, the relevance of the leader's role model, the rewarding policies for employees and good information systems.

\section{The basics: market orientation and organisational values}

Since the research on market orientation started, many scholars have developed the knowledge base further. Some comprehensive overview articles have been published (see for instance Cadogan and Diamantopoulos, 1995; Bisp, 1999; Laffarty and Hult, 2001; Rodriguez Cano et al., 2004; Kirca et al. 2005). Diamantopoulos and his co-authors successfully integrated the original Narver and Slater way of defining market orientation (emphasis on customer orientation, competitor orientation and interfunctional coordination) with the approach of Kohli and Jaworski (intelligence generation, intelligence dissemination and responsiveness).

Laffarty and Hult (2001) elaborate on the relationship between the managerial focus and the cultural focus taken in studies on market orientation. These authors hold that the cultural

\footnotetext{
${ }^{12}$ For a further description of these four assets and four capabilities see Hooley et al. (2001) or Hooley, Saunders and Piercy (book, 1998 or 2003).
} 
focus goes beyond the specific structures and formal and informal processes within an organisation. It relates to the fundamental values determining the actual practices in an organisation: the way people behave or the way they do things in that organisation. This cultural perspective also comes to the fore when the approach of a learning organisation has been taken in studies on market orientation (see for instance Slater and Narver, 1995; Baker and Sinkula, 1999). Slater (2001, p. 230) expressed this notion explicitly when stating "A market orientation is the aspect of business culture that motivates employees throughout the organization to place the highest priority on the profitable creation and maintenance of superior customer value. As such, it establishes norms for behavior regarding the organization-wide development of and responsiveness to information about customers and competitors, both current and potential." Slater distinguishes between the traditional and new approach to market orientation. "Market -oriented businesses have traditionally focused on understanding the expressed needs of the customers in their served markets and on developing products and services that satisfy those needs"(p. 230) In this way, market orientation is focusing on current products and services, incremental rather than breakthrough learning and the short term. Slater (2001, p. 231) continues by stating that the, "Second generation market-oriented businesses are committed to understanding both the expressed and unexpressed needs of their customers, and the capabilities and plans of their competitors through the processes of acquiring and evaluating market information in a systematic and anticipatory manner." Now, the focus is more on the long-term and on breakthrough learning. Again, we see the concept of market orientation relates to the values of any organisation: its culture.

Based on these notions we hold that as long as customer expectations are managed well and the competitive position has been taken into account, the organisation can always be market oriented. ${ }^{13}$ This is not exclusive to any generic strategy. Basically, it hinges upon meeting the values customers deem relevant. As Treacy and Wiersema (1995, p. 20) have pointed out, some customers view performance or uniqueness as the pivotal component of values, others most value personalised service and advice, and a third group looks largely for the lowest total cost. So, in our terminology, customers have different values that need to be satisfied by firms having a particular notion of their own market orientation. Based on this 'customervalue notion', Treacy and Wiersma (1995) developed their three value disciplines: product leadership, customer intimacy and operational excellence. Customer intimacy probably fits best to firms offering tailor made products and services, while operational excellence fits best to producing low cost standard products and services. In other words, some firms may be market oriented when they produce low cost products while others are market oriented when they produce high quality innovative products. ${ }^{14}$

\section{The cultural perspective on market orientation}

Several research projects on market orientation and its relationship with corporate culture have been carried out (e.g. Dunn, Norburn and Birley 1985; Mühlbacher, Vyslozil and Ritter 1987; Piercy and Peattie, 1988; Deshpandé and Webster 1989; Day 1990; Kohli and Jaworski 1990; Narver and Slater 1990; Ruekert 1992; Selness and Wesenberg 1992; Deshpandé, Farley and Webster, 1993; Dreher 1993; Diamantopoulos and Hart 1993; Day 1994; Greenley, 1995; Pelham and Wilson, 1996; Avlonitis and Gounaris, 1997; Piercy, 1997; Hurley and Hult, 1998; Narver and Slater, 1998; Baker and Sinkula, 1999; Day, 1999, Hooley et al. 2001). Cadogan and Diamantopoulos (1995) developed the concept of market

\footnotetext{
${ }^{13}$ In this way we have reformulated George Day's definition of market orientation presented earlier.

${ }^{14}$ An other argument for this way of reasoning, claiming that different strategies or cultures may be associated with the term market orientation, is given by George Day (2000). He provides examples of firms in one area of economic activities (retailing) having different strategies and market positioning while they are also perceived as highly market oriented. For, highly market oriented retailers like Walmart or Nordstrom follow very different strategies: a discounter and an upscale retailer.
} 
orientation further in an international context. In most of these studies, opinions have been given on the marketing practices in the respondent's firms which are then considered as the marketing culture in these firms. We question whether that is a valid and reliable approach given the one or two respondents per firm and the fact that the 'real culture' of the firm has not been measured.

Two articles about corporate culture have been very influential in the field of market orientation: Deshpandé and Webster (1989) and Deshpandé, Farley and Webster (1993). ${ }^{15}$ They define organisational culture as "the pattern of shared values and beliefs that help individuals understand organizational functioning and thus provide them with the norms for behavior in the organization." (1989, p.4; 1993, p. 24) In their research they have used the organisational cognition paradigm. This perspective allows for focussing on the information processing approach to market orientation. ${ }^{16}$ They applied the cultural typology as developed by Quinn (1988). Four types of organisational culture emerge from the combination of two key dimensions. One key dimension ranges from organic to mechanistic processes. This refers to whether the organisation puts more emphasis on flexibility, spontaneity and individuality or on control, stability and order. The second key dimension relates to internal maintenance or external positioning. This relates to the emphasis on smoothing activities and integration versus the emphasis on competition and environmental differentiation. Then four types of cultures can be defined:

- clan: organic and internal maintenance;

- $\quad$ hierarchy: mechanistic and internal maintenance;

- adhocracy: organic and external positioning;

- market: mechanistic and external positioning.

Their empirical study consisted of 200 personal interviews in 50 firms: two executives per firm and two of their customers. The study was done in Japan. It revealed market cultures are associated with the best performance followed by adhocracy, clan and hierarchical cultures. In another study in five countries (Japan, United States, France, Germany and England) they found again that market cultures exhibited the highest performance. However, now clans performed the worse. Innovativeness mattered the most in explaining differences in performance, closely followed by organisational culture and climate (Deshpandé, Farley and Webster, 1997).

In contrast with this view, Day (1999, p. 54 - 55) states "An adhocracy is most congruent with a market orientation because it values flexibility and adaptability while maintaining a primary focus on the external environment. Companies like General Electric, British Airways and Citibank seem to fit this profile. A market type of culture emphasizes competitiveness and goal achievement as well as productivity and market mechanisms. The aggressive style of PepsiCo. in both the beverage and Frito-Lay Snack Division fits this culture type."

In evaluating the results of the studies mentioned it appears that they do not lead to a common conclusion. It is not clear what type of culture leads to the best performance. However, it should be taken into account that the studies have been done in various countries each having its own national culture. This may affect the way companies deal with customers and hence their corporate cultures and market orientation. Moreover, quite a broad measure has been used to measure corporate culture. For instance, the market culture type is characterised by the existence of

- $\quad$ dominant attributes as competitiveness and goal achievement;

- $\quad$ leadership style emphasising decisiveness and achievement-orientation;

- $\quad$ bonding to the organisation via goal orientation, production and competition; and

\footnotetext{
${ }^{15}$ Also these two studies are subject to our criticism

${ }^{16}$ This information processing approach of market orientation is present in the definition provided by Kohli and Jaworski which focuses highly on 'intelligence' as well as in Narver and Slater's dimension of interfunctional coordination.
} 
- $\quad$ strategic emphasis on competitive advantage and market superiority.

So, the cultural aspect has been researched not deeply and detailed enough. It remains too superficial. The real values or dominant attributes of each of the four cultural types do not really come to the fore.

\section{Our approach to measuring corporate culture}

A more detailed measure of corporate culture has been developed conceptually by Hofstede (1991). He defines (p.180) corporate culture as "the collective programming of the mind which distinguishes the members of one organization from another". Moreover, he states (p.182 - 183), "shared perceptions of daily practices should be the core of an organisation's culture". Especially these practices should be researched when one wants to investigate corporate culture empirically. Corporate specific norms and values will be expressed and reflected in those practices.

Many other authors have published on corporate culture (e.g. Schein 1985, Trice and Beyer, 1993). Quite a few topics have been pinpointed as topics that are open for debate in this domain of organisational culture, like single cultures or multiple cultures, consensus versus dissensus, distinctive versus universal elements, or rigid versus malleable cultures (see e.g. Trice and Beyer, 1993, for an overview of the existing views on these topics). We hold that organisational cultures can be changed to a certain extent, especially by changing some of the practices that are considered to be the expression of the culture. In line with this 'practises approach to culture', we prefer to apply the Hofstede approach since it appears to be not only a validated instrument to measure such practices, but also because it appears to be very relevant and clear to managers. One of Hofstede's statements to measure corporate culture is phrased in terms of meeting customer needs. In that way, such a measurement instrument is already closely linked to our subject of market orientation. Applying the Hofstede scale also offers the opportunity to fine tune that measurement instrument with respect to an organisation's market orientation.

Hofstede has developed a number of questions to operationalise organisational culture in order to measure it empirically (Hofstede 1991, pp. 187 - 192). This measurement instrument has been validated in several case studies and will be used here. The scale consists of nineteen items (see table 1). These items can be grouped into six dimensions (within brackets the specific questions are mentioned):

1. process oriented versus results oriented $(\mathrm{C} 3, \mathrm{C} 8, \mathrm{C} 18)$;

2. employee oriented versus job oriented $(\mathrm{C} 2, \mathrm{C} 10, \mathrm{C} 11)$;

3. parochial versus professional $(\mathrm{C} 5, \mathrm{C} 9, \mathrm{C} 16)$;

4. $\quad$ open system versus closed system (C6, C12, C14);

5. loose control versus tight control (C4, C7, C13); and

6. normative versus pragmatic (C1, C15, C17, C19).

From the description of the nineteen items in table 1, it becomes clear that an organisation's (degree of) market orientation will come to the fore especially in the items upon which dimension six is built. Based on the content of this dimension, a market oriented organisation will be pragmatic in its culture: meeting customer needs has top priority, results are more important than following the correct procedures, the organisation is largely aware of the competition. This conclusion is more or less in line with a conclusion to be drawn from Deal and Kennedy's work indicating a higher degree of market orientation probably will be associated with a greater willingness to take (high) risks and a faster feed back on the results accomplished in the market place. So, in terms of the Hofstede dimensions, market orientation will be reflected also in the dimension of results orientation: accepting risks is considered to be normal practice in daily organisational life, people do their utmost best, each day brings new challenges. This is also the characteristic of professional firms. George Day (1999) holds that market oriented organisations have an externally oriented culture (p.6). In other words, this culture is an open and participative one (p. 7) and one in which people learn from failures or mistakes (p. 50). This refers to Hofstede's dimension of openness: market 
oriented organisations are open minded, accept almost everyone as a colleague, new employees feel at home very quickly. The participative element of culture might be reflected in loose control systems (dimension 5) and an interest in people (dimension 2). Such organisations will be managed professionally (dimension 3). So, we formulate the following propositions about the cultural features of market oriented organisations:

Proposition 1: $\quad$ The more market oriented organisations are, the more their culture will be characterised by a results orientation rather than a process orientation.

Proposition 2: $\quad$ The more market oriented organisations are, the more their culture will be characterised by an employee orientation rather than a job orientation.

Proposition3: $\quad$ The more market oriented organisations are, the more their culture will be characterised by a professional orientation rather than a parochial orientation.

Proposition 4: $\quad$ The more market oriented organisations are, the more open their culture will be rather than closed.

Proposition 5: $\quad$ The more market oriented organisations are, the more their culture will be characterised by a loose control system rather than a tight control system.

Proposition 6: $\quad$ The more market oriented organisations are, the more their culture will be characterised as pragmatic rather than normative.

\section{Our approach to measuring market orientation}

The studies on market orientation that have emphasized the cultural perspective investigate all kind of marketing practices that are supposed to reveal the market oriented culture of the organisation. As stated, we hold that is too simple as the only way of measuring the market oriented culture of an organisation. In this approach the culture as such is not measured, only the way it is reflected in some marketing practices. This is relevant of course, but only a partial approach to really identifying the way in which corporate culture and market orientation are linked together. To us, both the underlying culture of the company as well as the way in which it is reflected in the marketing domain should be measured. That is another reason why we discussed the Hofstede approach to measuring corporate culture. It offers the opportunity to measure these underlying factors. In our approach we intend to measure some practices reflecting the organisational culture in general and some marketing practices to measure the unique marketing practices belonging to a certain degree of market orientation. By measuring both kinds of practices we will be able to measure the culture of market oriented organisations. So, now we first have to look at what marketing practices could be relevant. ${ }^{17}$ Then we can combine the cultural characteristics as mentioned in the previous section with the marketing topics mentioned in this section.

The set of marketing variables taken into account, has not only been based upon the variables included in the Narver and Slater (1990) and Kohli and Jaworski (1990) studies. We also included issues related to the 'long term horizon' and 'profit emphasis' that were originally omitted from the 1990 Narver and Slater scale as well as topics from the studies performed by Ruekert (1992), Kohli, Jaworski and Kumar (1993), Hart and Diamantopoulos (1993), Cadogan and Diamantopoulos (1995), Greenley (1995a, 1995b), Siguaw and Diamantopoulos (1995), Gray, Matear, Boshoff and Matheson (1998), and Langerak (2001). ${ }^{18}$ Moreover, we included topics from studies on marketers' and consumers' attitudes and opinions about

\footnotetext{
${ }^{17}$ These practices can be regarded as the result of the implementation of the marketing strategy chosen.

${ }^{18}$ Langerak introduced the difference between upstream market orientation and down stream market orientation, depending on the position a company has in the distribution channel.
} 
particular topics in the domain of marketing and consumerism (Barksdale and Darden, 1972; Barksdale et al., 1982; Interview-IPM, 1974 and 1981; Gaski and Etzel, 1986). Finally, we included many issues from the PIMS studies by Buzzell and Gale (1987) and insights reported by Deal and Kennedy (1982) and Peters and Waterman (1982). We started our research in the late eighties and added new topics to the questionnaire that have proven to be relevant according to the research published on market orientation and our discussions with managers. So, the measurement instrument is quite dynamic and unique. The results of our studies over the past ten years may contribute to further fine tuning of the scale to measure the extent to which an organisation is market oriented.

The measurement instrument on market orientation has been developed as follows. First a list of all the marketing items from the above mentioned studies was made. This list of more than 200 statements was carefully checked for overlapping statements by the author and some colleagues. This led to a reduction of about 50\%. The remaining statements were used in the first smaller case studies. Analysing the correlations between the statements and correcting for the high correlations led to a shorter questionnaire of about 70 marketing statements. This one was applied in the first larger scale case study (the computer services company) in which 135 respondents participated. Such a case number of respondents offers the possibility to further reduce the dataset via factor analysis. The questionnaire that resulted after this procedure has been used in the case studies. Based on new insights in recent literature, some new statements have been added to the questionnaire. ${ }^{19}$

The marketing and management variables taken into account refer to eight categories of subjects. The items belonging to each category are mentioned in table 2 and are shown here within brackets. These eight categories are:

1. general issues about the efforts the organisation takes to be(come) market oriented and some underlying basic issues (M4, M9, M17, M25, M28, M30);

2. learning organisation (M16, M29);

3. customers (M1, M11, M12, M26);

4. $\quad$ competitors (M2, M3, M13);

5. employees (M15, M20, M22, M27);

6. commitment to marketing in the organisation (M10, M14);

7. coordination and dissemination of (marketing) information (M8, M18, M19, M21); and

8. new product/service development (M5, M6, M7, M23, M24).

Proposition 7: $\quad$ The more market oriented organisations are, the more they will be characterised by the basic features of marketing.

Proposition 8: $\quad$ The more market oriented organisations are, the more they will be characterised as learning organisations.

Proposition 9: $\quad$ The more market oriented organisations are, the better they know their present and future customers to meet their preferences.

Proposition 10: $\quad$ The more market oriented organisations are, the better they know their present and future competitors and provide better quality/value.

Proposition 11: $\quad$ The more market oriented organisations are, the more dedicated employees knowing what market orientation means (and acting accordingly) they will have.

${ }^{19}$ These newest items are not included in this paper, since there are not enough companies yet that have responded on these items. 
Proposition 12: $\quad$ The more market oriented organisations are, the greater their commitment to marketing at all levels in the organisation.

Proposition 13: $\quad$ The more market oriented organisations are, the more they will have a well coordinated process of collecting and disseminating marketing information throughout the organisation.

Proposition 14: $\quad$ The more market oriented organisations are, the closer they are to the market with respect to developing and launching successful new products and services.

Now that these propositions have been developed we can give a first indication of the proposed configuration of corporate culture and market orientation. That overview sets the general framework for the more detailed propositions that will be developed later.

The corporate culture - market orientation configuration in organisations

When the six propositions on corporate culture are combined with the eight propositions on market orientation we may tentatively propose that:

- $\quad$ the more market oriented organisations are;

- $\quad$ the more results oriented, employee oriented, professional, open, loosely controlled, and pragmatic organisations they are; and

- $\quad$ the more they will be characterised by the basic features of marketing, the more they will be characterised as a learning organisation, the more they will be committed to marketing, the more they will know about their markets (customers and competitors), the more they will know about market orientation and act on it, the better their relative quality will be, the better their process of collecting and disseminating market information will be, and the more successful they will be in launching new products and services.

Or stated in the reverse way, a process oriented, job oriented, parochial, close, strictly controlled and normative culture will be characterised by an absence of the basics of marketing and hence all the other features of marketing and market orientation as mentioned before. Consequently, such a culture is blocking a market oriented culture.

In order to measure the propositions 1 till 14 empirically, we had to operationalise the concepts as indicated before and shown in the Appendices 1 and 2. It would go too far to mention all the possible detailed hypotheses here. Therefore, we will focus on the correlation matrix in which the Pearson correlations between the average scores on each of the marketing statements and the culture statements for each of the cases have been provided (table 5). The cultural statements used are the ones stemming from the validated Hofstede studies on corporate culture. It hinges upon 19 items. One dimension is represented by four statements (the one on pragmatic and normative) while each of the other five dimensions is built up of three statements. Data on all 19 items are available for all cases. The list of marketing statements used in this analysis consists of 30 items. More statements have been used in the various case studies because all the questionnaires were customised or extended over time. The 30 items we report here are the items that belong to ten or more of the cases in the data base as used in this paper. Missing data have been substituted by the mean score of the existing data. ${ }^{20}$

\footnotetext{
20 This research program started at the end of the eighties and is based on the literature that existed at that time and our own insights. As the research went on, the new insights from the literature were added whenever possible. Therefore, the questionnaire has developed over time. Nevertheless, when comparing all the studies carried out, a number of items are incorporated in all studies. Those items will be used in this paper.
} 


\section{Research design}

In our study we have chosen to do multiple case studies to get further insight into these propositions. Next to the conceptual work, most of the academic research on market orientation hinges upon testing hypotheses in cross sections in many or a few industries. Most of the time, one or a few respondents per company complete the questionnaires or are interviewed. Since culture relates to the shared beliefs, we hold it is necessary to invite all the employees of an organisation to participate in the study. Moreover, we experienced in our pilot studies that managers have a different representation of reality in their company than employees on the shop floor. Therefore, we decided to do our research on corporate culture and market orientation on the basis of case studies.

In each company we ideally interviewed 10 to 15 randomly selected employees ${ }^{21}$. Then a questionnaire was mailed to all the employees. It always consisted of 19 items on corporate culture. Usually 35 statements on marketing practices were provided (this number may differ for it was tailored to the specific company in the case study) and finally 5 questions about the respondent's demographics. A pre-paid envelope was included to return the completed questionnaire to the researcher.

A wide variety of organisations have participated in our case studies thus far: both manufactures and service providers (see table 3). They were selected randomly. The first case studies were done in the late eighties; the last one to be reported here was completed in 2001. The response per organisation was quite representative for the whole organisation. Table 3 contains some basic information about our 26 cases.

The results of the qualitative part appeared to be in line with the results of the quantitative part. Moreover, presenting the results to the organisations investigated not only made the management teams say that they had face validity but also made them conclude that it was an appropriate reflection of what they were experiencing in their company. However, some unexpected findings were reported. Discussing these unexpected findings most of the time offered new insights to the companies as to why some actions or procedures were not working that well or why their perceptions differed from all employees. We concluded that the results of our studies were reliable and valid results, not only making sense but also reflecting the true situation in the company.

The mean scores for each organisation as to how the employees perceive their company's culture and market orientation have been used to do the analysis. However, using mean scores could lead to wonderful, though artificially high correlations, merely due to the fact that there is a tendency to the mean. Then the real value of the correlations is not depicted. Therefore, we have chosen to slightly modify our data base. Fortunately, some case studies had that many respondents that we could apply hierarchical cluster analysis to detect several clusters of market orientation within those companies. ${ }^{22}$ We have chosen to use the average scores per cluster within a particular company whenever it was possible to perform such an analysis instead of the overall mean scores for that large company. This could be done in four cases. In three of those four cases, four clusters could be detected. In one case, the results could be split in two clusters. The other 22 cases were too small to search for independent

\footnotetext{
${ }^{21}$ This number may be less when small organisations are investigated.

${ }^{22}$ The clustering has been based on all cultural and marketing statements in that particular company. Once these clusters were found, it was possible to see whether the respondents within one cluster belonged to the same age group, gender, department, etc. It appeared that some respondents were overrepresented in some clusters. However, it could not be concluded that it was always the case that for instance $100 \%$ of all employees in the sales or marketing department were in one cluster. In one of the insurance companies it even appeared that each of the four members of the Board of Directors was present in one of the four clusters found. This made them conclude: "now we understand why we have so much discussion on our way of marketing the company and cannot come to an agreement; we all have different perspectives of the market and our company within the market'.
} 
clusters or groups within the company. So, in fact we now have created a new dataset of 36 "cases / respondents" (=22 smaller cases plus $3 * 4$ clusters plus $1 * 2$ clusters $)$. This set has been used for our analysis. It consists of 12 manufacturers and 24 service providers (originally these numbers were 12 manufacturers and 14 service providers). ${ }^{23}$

\section{Findings}

The average item scores for all of the 36 cases are presented in table 4. Six statements show very clear opinions for the whole group of organisations. ${ }^{24}$ With respect to the culture statements this table reveals the respondents hold that employees always do their best in their jobs (C8; mean score 3,84), that the company has high standards with respect to ethics and fairness in doing business, even if it would damage short time results (C17; mean score 3,73) and that the people are well aware of competition (C19; mean score 2,17). With respect to the marketing statements the mean scores indicate that the respondents feel their own work is important for accomplishing the company's customer friendliness and service (M22; mean score 2,00), the company has many competitors in its industry (M3; mean score 2,07) and top management stress again and again that the focus should be on the customer (M10; mean score 2,25). ${ }^{25}$ This implies that, on average in this group, the organisations do not have strong opinions on their culture or marketing practices.

After this general overview it is important to have a closer look at the relationships between the variables representing corporate culture and those representing the market orientation. We will describe our results in terms of descending order of the correlations. We simply calculated the Pearson correlation coefficient.

Table 5 reveals that the culture statements with the highest number of significant correlations (top 3) deal with openness and transparency of the organisation (C6), the daily challenges (C18), and top priority is in meeting customer needs (C1). ${ }^{26}$ These statements represent topics from three different cultural dimensions, namely the open mindedness, the results orientation respectively the pragmatic side of the culture.

On the other hand, the top 5 of the marketing statements consists of the relative quality (M2), the company doing its utmost best (M17), the existence of clearly formulated marketing goals (M9), knowledge about the customers (M11), and encouraging feed back from the market place (M16). These items refer to issues from four different dimensions within the market orientation scale: general issues (utmost best, clear marketing goals), learning organisation (feed back from the market), customers (knowledge on them) and competitors (relative quality).

This is a first indication of the items that probably will be relevant in the corporate culture market orientation configuration. At the same time it appeared that three cultural statements did not have any significant correlations with the marketing statements: the impact of the organisation's norms at work and at home; all people fit in the organisation or only special ones; and, awareness of competition. These three belong to three different cultural

\footnotetext{
${ }^{23}$ Only the statements that were used in ten or more case studies are involved in our data analysis, otherwise the minimum number of 'respondents' per item would be too small. The missing data have been substituted by the mean scores of the existing data. Correlations found here are very much in line with the correlations found in each case study; consequently, this procedure of dealing with missing values is not creating artificial results.

${ }^{24}$ Here we applied the rule of thumb indicating that scores smaller or equal to 2.30 and scores equal to or larger than 3.70 give clear opinions on the statements (on these 5 point - Likert and cultural - scales)

${ }^{25}$ It may be that the answer to the issue of one's own work's importance to accomplishing customer friendliness and service is based on some kind of social desired answering. However, if respondents said their work would be of no importance to that, it would be a disaster.

26 A further look at the data reveals these three culture items are quite correlated to one another: giving top priority to meeting customer needs and openness and each day is challenging. Their Pearson correlation coefficients are between .70 and .75; these are significant at the .01 level.
} 
dimensions. It also appeared that five marketing statements did not correlate significantly to any cultural statement. Two of them are part of the general topics (delivery times, clearly formulated company goals); the others belong to different topics, like competitors (many competitors), employees (doing more for the customer than agreed upon) and new product/service development (risky). So, these are also not concentrated in one particular topic. Consequently, the significant correlations hinge upon a wide variety of topics from all cultural and marketing topics in our questionnaire.

Analysing the sizes of the many significant Pearson correlation coefficients reveals sixteen of them are equal to or greater than +.75 or equal to or smaller than $-.75 .{ }^{27}$ These can be considered as the most important ones determining the configuration of market orientation and organisational culture. They are:

- $\quad$ an open culture is positively correlated to clarity about the things that have to be done for the customer (C6xM26: .86);

- $\quad$ not having high ethical standards is positively correlated to looking after the self interest of departments (C17xM28: .85);

- $\quad$ each day is pretty much the same is negatively correlated to the clear communication about new plans and changes affecting someone's own work (C18xM19: -.84);

- $\quad$ an open culture is positively correlated to our company does its utmost best to be the best (C6xM17: .82);

- $\quad$ an open culture is positively correlated to learning from each others' mistakes (C6xM29: .82);

- $\quad$ meeting customer needs as top priority is negatively correlated to departments looking after their own interest (C1xM28: -.82);

- $\quad$ an open culture is negatively correlated to a poor cooperation between departments (C6xM18: -.81);

- $\quad$ each day is pretty much the same is correlated negatively to a good internal communication about new plans on operating in the market (C18xM21: -78);

- $\quad$ an open culture is positively correlated to a good internal communication about new plans and changes affecting one's own work (C6xM19: .78);

- $\quad$ an open culture is positively correlated to a good internal communication about new plans on operating in the market (C6xM21: .78);

- $\quad$ each day is pretty much the same is positively correlated to a poor cooperation between departments (C18xM18: .77);

- $\quad$ an open culture is positively correlated to a relative better quality of products and services offered (C6xM2: .77);

- $\quad$ meeting customer needs has top priority is positively correlated to encouraging feed back from the market (complaints and compliments) (C1xM16: .76);

- the organisation is only interested in the work delivered is negatively correlated to a relative better quality of products and services offered (C10xM2: -.75)

- $\quad$ an open culture is positively correlated to encouraging feed back from the market (complaints and compliments) (C6xM16: .75); and

- $\quad$ new employees need only a few days to feel at home is positively correlated to it is always clear what the customer wants and what job has to be done when we start that job (C14xM26: .75).

This overview reveals again the critical position of an organisation's open culture dimension with respect to market orientation: nine of these sixteen highest correlations deal with the openness feature of the organisation's culture. The openness is positively correlated to

\footnotetext{
${ }^{27}$ If we mentioned all the statistically significant correlations, this overview would be too long to be useful. Table 5 contains all the information.
} 
- $\quad$ a general marketing feature (the drive to be the best);

- $\quad$ two features of a learning organisation (encouraging feed back from the market place and learning from each other's mistakes);

- $\quad$ a feature of the customer part of the market orientation (clarity about the work to be done for the customer);

- $\quad$ a feature from the competitive part of market orientation (better relative quality) and

- $\quad$ three features from the coordination and dissemination of market intelligence (excellent cooperation between departments within the organisation and two items on excellent internal communication).

Three other high correlations refer to the process part of the process/results dimension in an organisation's culture: daily stability is correlated positively to poor cooperation between departments and is correlated negatively to excellent internal communications. In other words, a challenging environment (belonging to a results orientation) is positively correlated to excellent cooperation and internal communication.

Three other high correlations are to be found in the normative/pragmative dimension of corporate culture. Meeting customer needs as top priority has been correlated negatively to pursuing self interest (which in turn is correlated positively to the cultural item of 'the end justifies the means') and positively to encouraging feed back from the market. So a pragmatic part of the culture would correlate positively to a lack of pursuing self interest and the feed back from the market; the normative part reflects the ethics and fairness in doing business even it could damage the company's results in the short run.

One statement from the employee/job orientation in the culture (the organisation is only interested in the work to be done) is correlated negatively to the relative better quality of the product and services offered. In other words, interest in people (employee orientation) is positively correlated to a relative better quality.

Finally, analysing the results for both the parochial-professional dimension as well as the loose - tight control dimension does not reveal many very high correlations. As a general comment we may deduce from these results that market orientation and a long time perspective (professional) go hand in hand. It seems to be the case that if control is strict (e.g. the marketing philosophy is clearly visible, clear marketing goals exist) on one hand, it is loose on the other hand (employees may organise their work based on guidelines from their bosses). Obviously, the framework has been set in which the empowered people may work on the basis of a balanced control system. Also the correlations between the issues about new product/service development and the cultural items are not that high. Generally it is thought that the employees developing new products and services have close contact with the market and indicate that people always do their utmost on challenging days.

\section{Conclusion and discussion}

In comparing the findings with our propositions we conclude that most of the propositions have been supported. Table 5 reveals significant correlations between the issues relating to each of the six cultural dimensions and each of the eight marketing dimensions. However, some modifications have to be made. As proposed the results indicate that the corporate culture of market oriented organisations is indeed open, results oriented, employee oriented and professional (long term perspective) but is also balanced on the dimensions of pragmative/normative and tight/loose control. Contrary to these last findings, it was proposed - however - that the culture would be pragmative and have a loose control system. So, these two propositions are not supported.

Table 5 reveals a large number of correlations. Based on the highest correlations, it can be concluded that the most important building blocks of the market oriented corporate culture are:

- $\quad$ from the cultural side:

its openness; 
and, from the marketing side:

its results orientation;

its balanced pragmatic (customer needs) and normative (high ethics)

culture; and

its employee orientation;

- $\quad$ its internal cooperation and internal communication (as issues on the coordination and dissemination of information throughout the organisation);

- $\quad$ its drive to be the best, lack of pursuing self-interest (as examples of general issues);

- $\quad$ its learning from mistakes and encouraging feed back from the market (as issues on the learning organisation);

- $\quad$ its clarity about the work to be done for the customer (as an issue from the customer orientation); and

- $\quad$ its better relative quality of products and services offered than competitors' (as an issue from the competitor orientation).

Presumably, these are the most significant and important issues in the market orientation corporate culture configuration. When we combine these findings into one picture, figure 2 emerges. This figure should be read as follows. The rectangles represent marketing issues while the circles represent cultural issues. The figure has been made to represent positive relationships between topics. In fact, based on the most prominent correlations found, a configuration of many different interrelated issues is shown revealing the corporate culture market orientation configuration.

Consequently, when an organisation intends to change its market orientation, its strategy or its culture, this figure shows which features are the most important ones managers should change in order to accomplish their goals. So, managers will see what cultural issues and marketing issues have to be changed in order to be in line with one another as suggested by the corporate culture market orientation configuration. ${ }^{28}$ For instance, encouraging feed back from the market or improving the internal communication will contribute to creating a more open culture. Or, in other words, when every employee or department is pursuing its own interest, it is not likely that customer needs will get top priority and that feed back from the market is encouraged; the organisation will stay closed to a large extent, cooperation between departments will be poor and internal communication will be inefficient. So, Figure 2 provides the information on the issues that should be subject to change management in order to become really market oriented. In fact, figure 2 hinges partly upon the outside -in capabilities of market oriented organisations in turbulent environments, but also the other capabilities mentioned are represented. Having many competitors as such is not an issue here; it is important to have a better relative quality than the others by doing its utmost and knowing exactly what customers want.

Broadly speaking, the results of these case studies are in line with the results from the crosssectional studies on market orientation referred to at the beginning of this paper. However, here we have measured corporate culture itself. Now the fundamental underpinning upon which the marketing actions are based, has been made explicit. Although openness has been mentioned before as a characteristic of market oriented firms (Day, 1999) as well as the importance of the HRM factor (Heskett, Sasser and Schlesinger, 1997), this research shows that even more cultural features are at stake, namely the professional orientation, the results orientation, the balance between a pragmatic and normative culture and - finally - the

\footnotetext{
${ }^{28}$ With this graph we can also avoid the discussion on 'whether it is possible to change any culture'. For, it is now possible to work - very pragmatic - on changing some of the marketing actions which in turn might induce the changes in the culture.
} 


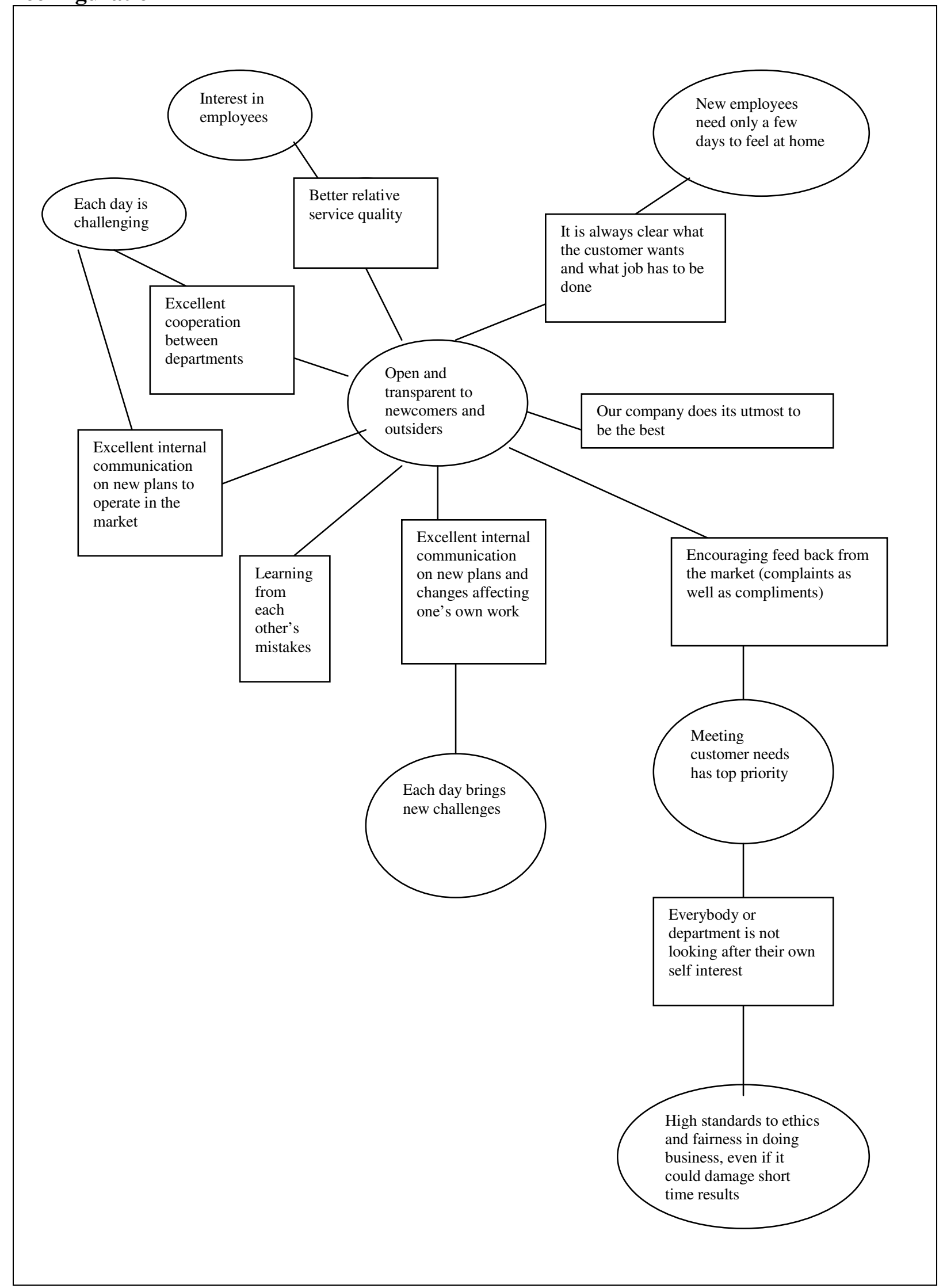

balanced control system. Only when this culture is changed, can the market orientation of the organisation be put into practice. Just changing some marketing actions to become market oriented is not sufficient nor efficient. 
Given the findings about the relevance of interests in employees and customers, organisations showing a great care in (these) people do have the conditions set to accomplish a better relative quality. The combination of knowledge about competitors and customers is said to be the combination to have a market driven strategy. Care for people is also reflected in setting and communicating clear targets. Then the employees know the framework in which they are working, in which they can exercise their responsibility and empowerment. If this reasoning holds, that might explain partly why the relationship between market orientation and performance is stronger for service organisations than in manufacturing (Rodriguez Cano et al. 2004).

\section{Limitations and further research}

This study has taken a different methodological approach to existing ones that focus on large scale cross sectional analysis. This new case study approach has proven to be promising and revealing more in depth insights than the others on measuring corporate culture as the shared beliefs and the accompanying market orientation. The number of cases available is a limitation of this study. Also, the majority of the case studies have been undertaken in The Netherlands (with one in the UK). It may be that the findings are culturally bound in the sense that the findings are typical for the Dutch national culture. Mavondo (1999), for instance, found that the psychometric properties of the Narver and Slater market orientation scale differed across countries (in his case Australia and Zimbabwe). Therefore, more case studies should be done in other countries representing different national cultures in order to investigate the culturally boundedness of market orientation.

In general, more case studies should be done to enlarge the data base. A larger data base allows for more sophisticated statistical analysis than performed here. Especially when more cases are similar on the same statements measured (and the missing values have not to be substituted by the means of the existing scores), factor analysis could be used to eventually further reduce the dataset (and avoid the complicated pictures that are required to represent all the significant correlations as in figure 2). In this paper we have refrained from in depth analysis of the correlations between the marketing items themselves as well as the cultural items themselves. This topic should be taken into account in further research. These case studies have not focused on the financial and non financial performance of the organizations investigated. This topic should be added in future case studies.

The same holds for the leadership styles appropriate to a market oriented culture. For example, Day (1999) contended that an aggressive style would fit, while Harris and Ogbonna (2001) and MacKenzie (2001) indicate that a transformational leadership would fit very well. It might even be that a combination of instrumental and transformational leadership is needed in market oriented cultures (just as it is the case in the combination of the two generic strategies to be market oriented: low cost strategies and differentiation Day, 1990; Mavondo, 1999). Leaders set the tone for the organisation's culture and its values. Therefore, more research on leadership style, corporate culture and market orientation should be carried out in the near future. The management literature contains a lot of leadership styles that have been developed and validated in many studies (see for instance Blanchard, 1985; Quinn, 1988; Goleman, 1998; Dessler, 2002; Robbins and Coulter, 2002). Those concepts could be applied easily in this kind of studies. Leaders are supposed to have six characteristics distinguishing them from non-leaders:

- drive: high effort level, high desire for achievement, ambitious;

- $\quad$ desire to lead: strong desire to influence and lead others;

- $\quad$ honesty and integrity: they build trusting relationships between themselves and followers;

- $\quad$ self-confidence: that is the way to convince followers;

- intelligence: in order to cope with a lot of information and to create visions, solve problems, and make correct decisions; 
- $\quad$ job-relevant knowledge: they have in-depth knowledge about the company, its products and services, industry, etc. to make well-informed decisions.

Many of these issues also come to the fore in the characteristics of market oriented firms as we have seen. But, all of them can be exercised in a particular way. Whichever styles that exist can determine the specific type of leadership in a market oriented organisation that will motivate the employees to serve the customer to the best of their ability and certainly better than their competitors. . 


\section{REFERENCES:}

Avlonitis, George J. and Spiros P. Gounaris (1997), "Marketing Orientation and Company Performance: Industrial vs. Consumer Goods Companies", Industrial Marketing Management, Vol. 26, issue 5, pp. 385-402.

Baker, William E. and James M. Sinkula (1999), "The synergistic effect of market orientation and learning orientation on organizational performance", Journal of the Academy of Marketing Science, Vol. 27, No. 4, pp. 411-427.

Barksdale, Hiram C. and Bill Darden (1972), "Marketers' Attitudes Toward the Marketing Concept," Journal of Marketing, 35 (October), 29-36.

Barksdale, Hiram C., William D. Perreault jr., Johan Arndt, J.A. Barnhill, W.A. French, M. Halliday and J. Zif (1982), "A Cross-National Survey of Consumer Attitudes toward Marketing Practices," Columbia Journal of World Business, 71-86.

Bisp, Sören (1999), Barriers to Increased Market-Oriented Activity: What the Literature Suggests, Journal of Market-Focused Management, 77-92.

Blanchard, K.H. Zigarmi, P. and D. Zigarmi (1985), Leadership and the One-Minute Manager: Increasing Effectiveness through Situational Leadership, William Morrow and Company, New York, NY.

Buzzell, Robert D. and Gale, Bradley T. (1987), "The PIMS Principles: linking strategy to performance," New York: The Free Press

Cadogan, John W. and Adamantios Diamantopoulos(1995), "Narver and Slater, Kohli and Jaworski and the Market Orientation Construct: Integration and Internationalization, "Journal of Strategic Marketing, Vol. 3, Issue 1.

Caruana, A., Pitt, L. and Pierre R. Berthon (1996), "Market Orientation and Business Performance: Some European Evidence," International Marketing Review, Vol.13, Issue 1.

Day, George S. (1990), Market-Driven Strategy; Processes for Creating Value, New York: The Free Press.

Day, George S. (1994), “The Capabilities of Market-Driven Organizations,” Journal of Marketing, 58 (October), 37-52.

Day, George S. (1999), The Market Driven Organization: Understanding, Attracting, and Keeping Valuable Customer, New York: The Free Press.

Deal, Terrence E. and Allan A. Kennedy (1982), Corporate Cultures: The Rites and Rituals of Corporate Life, Reading Ma: Addison-Wesley.

Deshpandé, R., Farley, J. and Frederick E. Webster, Jr. (1993), "Corporate Culture Customer Orientation and Innovativeness in Japanese Firms: A Quadrad Analysis," Journal of Marketing, Vol.57, Issue 1.

Deshpande, Rohit, and Frederick E. Webster, Jr. (1989), "Organizational Culture and Marketing: Defining the Research Agenda," Journal of Marketing, 53 (January), 3-15. 
Dessler, D. (2002) "Democracy, Liberalism and War," American Political Science Review, Vol. 96, Issue 3.

Diamantopoulos, Adamantios and Susan Hart (1993), "Linking Market Orientation and Company Performance: Preliminary Evidence on Kohli and Jaworski’s Framework," Journal of Strategic Marketing, 1, 93-121.

Dreher, Angelika (1993), "Marketing Orientation: How to Grasp the Phenomenon," in Marketing for the New Europe: Dealing with Complexity, Proceeding XXII EMAC Conference, Joseph Chias and Joan Sureda, eds. Barcelona, 375-393.

Dunn, Mark G., David Norburn, and Sue Birley (1985), "Corporate Culture, a Positive Correlate with Marketing Effectiveness," International Journal of Advertising, 4, 6573.

Fombrun, Charles J. (1983) "Corporate Culture, Environment and Strategy," Human Resource Management, Vol.22, Issue 1/2.

Fombrun, Charles J. (1984) "Structures of Organizational Governance," Human Relations, Vol.37, Issue 3, pp.207-223.

Gaski, J.F. and H.J. Etzel (1986), "The Index of Consumer Sentiment toward Marketing," Journal of Marketing, 50, 71-81.

Goleman, D. (1998), “Leader?” Harvard Business Review, Vol.76, Issue 6.

Grant, Robert M. (1991), "The Resource-Based Theory of Competitive Advantage: Implications for Strategy Formulation," California Management Review (Spring), 114-35.

Gray, B., Matear, S., Boshoff and Matheson (1998), "Developing a Better Measure of Market Orientation," European Journal of Marketing, Vol.32, issue 9/10.

Greenley, G.E. (1995a), "Market Orientation and Company Performance: Empirical Evidence from U.K. Companies," British Journal of Management, Vol.6, Issue 1.

Greenley, G.E. (1995b), "Forms of Market Orientation in UK Companies," Journal of Management Studies, Vol.32, Issue 1.

Han, J., Kim N. and Rajendra K. Srivastava (1998), "Market orientation and Organizational Performance: is Innovation a Missing Link?” Journal of Marketing, Vol.62, Issue 4.

Harris, Loyd C. and Ogbonna, E. (2001), Leadership Style and Market Orientation: An Empirical Study," European Journal of Marketing, Vol.35, Issue 5/6.

Hart, S. and Diamantopoulos, A. (1993), "Linking Market Orientation and Company Performance: Preliminary Evidence on Kohli and Jaworski's Framework," Journal of Strategic Marketing, Vol.1, Issue 2.

Heskett, James L., Sasser Jr, W.E. and Leonard A. Schlesinger (1997), "What is Strategy?" Harvard Business Review, Vol.75, Issue 2. 
Hofstede, Geert (1991), Cultures and Organizations: Software of the Mind, London: McGraw-Hill Book Company.

Hooley, G., Greenley, G., Fahy J. and Cadogan, J. (2001),'Market-focused Resources, Competitive Positioning and Firm Performance," Journal of Marketing Management, Vol.17, Issue 5/6.

Hooley, Graham J., Saunders, John A. and Piercy, Nigel F.(1998), "Marketing Strategy and Competitive Positioning," London: Prentice Hall Europe.

Hunt, Shelby D. (2001), "Commentary: A General theory of Competition: Issues, Answers and an invitation", European Journal of Marketing, Vol. 35, nr. 5/6, pp. 524-48.

Hunt, Shelby. D. and Robert M. Morgan (1995), "The Comparative Advantage Theory of Competition", Journal of Marketing, Vol. 59, April, pp. 1-15.

Hunt, Shelby. D and Robert M. Morgan (1996), "The Resource-advantage theory of competition: dynamics, path dependencies, and evolutionary dimensions", Journal of Marketing, vol. 60, October, pp. 107-14.

Hurley, Robert F. and Hult, G. (1998), "Innovation, Market Orientation and Organizational Learning: An Integration and Empirical Examination," Journal of Marketing, Vol.62, Issue 3.

Interview-IPM (1974 and 1981), Consumentisme, een Onderzoek naar de Consument in een Veranderende Samenleving, Amsterdam/Schiedam.

Kirca, Ahmet H., Jayachandran, Satish and William O. Bearden (2005), Market Orientation: a Meta-Analytic Review and Assessment of Its Antecedents and Impact on Performance, Journal of Marketing, April, vol. 69, Issue 2, 24-41.

Kohli, Ajay K. and Bernard Jaworski (1990), "Market Orientation; The Construct, Research Propositions, and Managerial Implications," Journal of Marketing, 54, (April), 1-18.

Kohli, Ajay K., Bernard Jaworski and Kumar (1993), "MARKOR: A Measure of Market orientation," Journal of Marketing Research, Vol.30, Issue 4.

Lafferty, Barbara A. and G. Tomas M. Hult (2001), "A synthesis of contemporary market orientation perspectives", European Journal of Marketing, vol. 35, no. 1/2, pp. 92-109.

Langerak, F. (2001), "Effects of Market orientation on the Behaviors of Salespersons and Purchasers, Channel Relationships and Performance Manufacturers," International Journal of Research in Marketing, Vol.18, Issue 3.

Lukas, Bryan A. and Ferrell, O.C. (2000), "The Effect of Market Orientation on Product Innovation,” Journal of the Academy of Marketing Science, Vol.28, Issue 2.

MacKenzie, S.B., Podsakoff, P.M and G.,A. Rich (2001), Transformational Leadership and Salesperson Performance, Journal of the Academy of Marketing Science, Vol. 29, Issue 2, 115-135. 
Matear, Sheelagh, Osborne, Phil, Garrett, Tony and Brendan J. Gray (2002), "How Does Market Orientation Contribute to Service Firm Performance? An Examination of Alternative Mechanisms", European Journal of Marketing,_vol. 36, nr. 9/10, pp. 10581075 .

Matsuno, Ken and John T. Mentzer (2000), "The Effects of Strategy Type on the Market Orientation-Performance Relationship", Journal of Marketing, vol. 64, nr. 4, pp. 1-16.

Mavondo, Felix T. (1999), "Market Orientation: Scale Invariance and Relationship to Generic Strategies Across Two Countries", Journal of Market Focused Management, vol. 4, pp. 125-142.

Miller, Danny (1986), "Configurations of Strategy and Structure: Towards a Synthesis," Strategies Management Journal, 7, 233-50.

Miller, Danny and Henry Mintzberg (1983), "The Case for Configuration." in Gareth Morgan (ed.), Beyond Method: Strategies for Social Research, Sage Publications.

Mühlbacher, Hans, Wilfried Vyslozil and Angelika Ritter (1987), "Strategic Marketing and Corporate Culture - an Analysis of Fit," in Contemporary Research in Marketing, Proceedings XVI EMAC Conference, Peter S.H. Leeflang and Marshall Rice, eds. Toronto, WB32-46.

Narver, John C. and Stanley F. Slater (1990), "The Effect of a Marketing Orientation on Business Profitability," Journal of Marketing 54 (October), 20-35.

Narver, John C. and Stanley F. Slater (1998), "Customer-Led and Market-Oriented: Let's Not Confuse the Two," Strategic Management Journal, Vol.19, Issue 10.

Pelham, Alfred M. and David T. Wilson (1996), A Longitudinal Study of the Impact of Market Structure, Firm Structure, Strategy, and Market Orientation Culture on Dimensions of Small-Firm Performance," Journal of the Academy of Marketing Science, Vol.24, Issue 1.

Peters, Thomas J. and Richard H. Waterman (1982), In Search of Excellence: Lessons from America's Best-Run Companies, New York: Harper and Row.

Piercy, Nigel and Kenneth J. Peattie (1988), "Matching Marketing Strategies to Corporate Culture: The Parcel and The Wall," Journal of General Management, Vol.13, Issue 4.

Quinn, R.E. (1988), “Beyond Rational Management,” Jossey-Bass, San Francisco, CA

Robbins, S.P. and M. Coulter (2002), Management, Prentice-Hall, Upper Saddle River, NJ.

Rodiguez Cano, Cynthia, Carrillat, Francois A. and Fernando Jaramillo (2004), "A MetaAnalysis of the Relationship Between Market Orientation and Business Performance: Evidence from Five Continents", International Journal of Research in Marketing, vol 21, pp. 179-200.

Ruekert, Robert W. (1992), "Developing a Market Orientation: An Organization Strategy

Perspective," International Journal of Research in Marketing, 9, 225-45. 
Sargeant, A. and Mohamad, M. (1999), "Business Performance in the UK Hotel Sector: Does it pay to be Market Driven?” Service Industries Journal, Vol.19, Issue 3.

Schein, Virginia E. (1985),"Organizational Realities: The Politics of Change," Training \& Development Journal, Vol. 39, Issue 2.

Selnes, Fred and Peter Wesenberg (1992), Organizational Processes in Becoming More Market Oriented, Sandvika: Norwegian Institute for Research in Marketing, Working Paper 92-09.

Siguaw, Judy A. and Adamantios Diamantopoulos (1995), "Measuring Market Orientation: Some Evidence on Narver and Slater's Three-component Scale," Journal of Strategic Marketing, Vol.3, Issue 2.

Slater, Stanley F. (2001), "Market orientation at the beginning of a new millennium", Managing Service Quality, Vol. 11, nr. 4, pp. 230-232.

Slater, Stanley and John C. Narver (1995), "Market orientation and the learning organization", Journal of Marketing, Vol. 59, July, pp. 63-74.

Tichy, Noel M. (1982)," Managing Change Strategically: The Technical, Political, and Cultural Keys," Organizational Dynamics, Vol. 1, Issue 2, p59-80.

Treacy, Michael and Fred Wiersema (1995), "The Discipline of Retail Market Leaders," Chain Store Age Executive with Shopping Center Age, Vol. 71, Issue 4

Trice, Harrison M. and Janice M. Beyer (1993), "The Cultures of Work Organizations," Englewood Cliffs, New York: Prentice Hall. 
C1 Meeting customer needs has top priority VERSUS The correct application of procedures has top priority

C2 There is a strong pressure to get the work done; personal problems come second VERSUS Personal problems are always taken care of; work comes second

C3 People feel ill at ease in unfamiliar situations; they try to avoid risks VERSUS People feel at ease in unfamiliar situations; they do not mind taking risks

C4 Employees have detailed instructions from their bosses concerning their work VERSUS Employees may organise their work along overall guidelines provided by their bosses

C5 We think only one day ahead VERSUS We think three years or more ahead

C6 The organisation and its people are open and transparent to newcomers and outsiders VERSUS The organisation and its people are closed and secretive to newcomers and outsiders

C7 Everybody is very cost conscious regarding time and materials VERSUS No one ever thinks of the cost of time and materials

C8 People make only limited effort in their jobs VERSUS People always do their best in their jobs

C9 The organisation's norms cover people's behaviour at work as well as at home VERSUS People's private life is their own business

C10 The organisation is only interested in the work delivered VERSUS The organisation takes direct responsibility for the personal well being of their employees and their families

C11 Managers try to keep good people in their department VERSUS Managers try to help people grow in the company

C12 Almost anyone would fit in the organisation VERSUS Only very special people fit into the organisation

C13 Meeting times are kept punctually VERSUS Meeting times are kept approximately

C14 New employees need only a few days to feel at home VERSUS New employees need more than a year to feel at home

C15 Results are more important than following the correct procedures VERSUS Correct procedures are more important than results

C16 People with the appropriate family, social class or school have better chance to get appointed VERSUS Ability to do the job is the only criterion for hiring people; their background does not affect the decision

C17 We do not have that high standards with respect to ethics and fairness in doing business; the end justifies the means VERSUS We have high standards with respect to ethics and fairness in doing business, even if it would damage short time results

C18 Each day is pretty much the same VERSUS Each day brings new challenges

C19 We are very well aware of competition from other organisations VERSUS We are not aware of competition from other organisations. 


\section{Table 2 The market orientation statements}

M1 Our company has a unique marketing policy for every segment of the market

M2 The quality of our services is better than our competitors'

M3 Our company has many competitors in the industry

M4 Our company provides extensive after sales service

M5 New service introductions are often adaptations and modifications of existing services

M6 Developing new services is risky to us

M7 Launches of new services have often failed for our company

M8 The exchange of information between the various departments is poor

M9 At our company clearly formulated marketing goals exist

M10 Top management stresses again and again that the focus should be on the customer

M11 Our company knows all its present customers superficially

M12 Our company has a unique marketing policy for every customer

M13 Our company is not aware of the present activities of competitors

M14 The marketing philosophy is visible everywhere within our company

M15 At our company everybody sees themselves more as providers of services to solve consumer problems rather than sellers of services

M16 Our company encourages all customers to voice complaints and give suggestions

M17 Our company does its utmost to be the best

M18 Cooperation between the various departments is poor

M19 New plans and changes which affect my own work directly are communicated well and clearly

M20 Everybody knows what our customer friendliness and service mean

M21 New plans about the way our company will operate in the market are communicated well and clearly to employees

M22 My own work is important for accomplishing our company's customer friendliness and service

M23 Our company often launches new products

M24 At our company, those people developing new services have many contacts with the market

M25 Delivery times cannot be postponed

M26 It is always clear what the customer wants and what job has to be done when we start that job

M27 Employees often do more for our customers than has been agreed upon in the contract

M28 At our company every department is looking after its own interest

M29 At our company we learn form each others' mistakes

M30 At our company clearly formulated company goals exist. 


\section{Table 3 The cases}

* Only the management team or higher management levels completed the questionnaire.

\begin{tabular}{|l|c|c|c|}
\hline Industry & Year & $\begin{array}{c}\text { Number of } \\
\text { respondents }\end{array}$ & $\begin{array}{c}\text { Response } \\
\text { rate }\end{array}$ \\
\hline Brewery* & 1989 & 11 & $100 \%$ \\
\hline Publisher & 1989 & 11 & $91 \%$ \\
\hline Marketing consultancy* & 1989 & 12 & $100 \%$ \\
\hline Tile manufacturer & 1990 & 135 & $34 \%$ \\
\hline Computer services & 1990 & 135 & $30 \%$ \\
\hline Fashion retailer (4 clusters now) & 1991 & 595 & $47 \%$ \\
\hline Insurances (4 clusters now) & 1992 & 340 & $73 \%$ \\
\hline Engineering consultancy & 1995 & 71 & $78 \%$ \\
\hline Health care (revalidation center)* & 1996 & 9 & $100 \%$ \\
\hline Public Waste Management* & 1996 & 14 & $100 \%$ \\
\hline City hall & 1996 & 70 & $70 \%$ \\
\hline Insurances (4 clusters now) cz & 1996 & 789 & $63 \%$ \\
\hline Research agency & 1996 & 14 & $100 \%$ \\
\hline Social welfare & 1996 & 120 & $50 \%$ \\
\hline Retail bank M & 1996 & 70 & $70 \%$ \\
\hline Chemical factory* & 1997 & 12 & $100 \%$ \\
\hline Chemical factory* & 1997 & 12 & $100 \%$ \\
\hline Chemical factory* & 1997 & 12 & $100 \%$ \\
\hline Steel manaufacturer (UK) & 1997 & 46 & $21 \%$ \\
\hline Retail bank D & 1998 & 29 & $76 \%$ \\
\hline Insurance broker (2 clusters now) & 1998 & 36 & Can not be \\
& & 1964 calculat \\
\hline $\begin{array}{l}\text { Manufacturer of industrial } \\
\text { equipment }\end{array}$ & 1999 & 23 & $77 \%$ \\
\hline Cement manufacturer & 1999 & 114 & $48 \%$ \\
\hline Food manufacturer & 1999 & 8 & $100 \%$ \\
\hline Manufacturer of rubber products & 1999 & 18 & $72 \%$ \\
\hline Manufacturer of plastic products & 1999 & 18 & $70 \%$ \\
\hline
\end{tabular}


Table 4 Mean scores on all culture and marketing items for all the 36 cases

\begin{tabular}{|c|c|c|c|c|c|}
\hline Culture & $\mathbf{N}$ & Mean score & Marketing & $\mathbf{N}$ & Mean score \\
\hline $\mathrm{C} 1$ & 36 & 2,48 & M1 & 31 & 2,90 \\
\hline $\mathrm{C} 2$ & 36 & 2,54 & M2 & 36 & 2,55 \\
\hline C3 & 36 & 2,98 & M3 & 36 & 2.07 \\
\hline $\mathrm{C} 4$ & 36 & 3,60 & M4 & 36 & 2,35 \\
\hline C5 & 36 & 3,19 & M5 & 30 & 2,38 \\
\hline C6 & 36 & 2,54 & M6 & 36 & 3,00 \\
\hline C7 & 36 & 2,57 & M7 & 30 & 3,40 \\
\hline C8 & 36 & 3,84 & M8 & 36 & 2,83 \\
\hline C9 & 36 & 3,37 & M9 & 34 & 2,65 \\
\hline C10 & 36 & 2,92 & M10 & 36 & 2,25 \\
\hline C11 & 36 & 2,87 & M11 & 36 & 3,23 \\
\hline C12 & 36 & 2,85 & M12 & 31 & 3,31 \\
\hline C13 & 36 & 2,94 & M13 & 30 & 3,60 \\
\hline C14 & 36 & 2,55 & M14 & 36 & 3,03 \\
\hline C15 & 36 & 2,56 & M15 & 30 & 2,88 \\
\hline C16 & 36 & 3,55 & M16 & 33 & 2,69 \\
\hline C17 & 36 & 3,73 & M17 & 33 & 2,39 \\
\hline C18 & 36 & 3,51 & M18 & 27 & 3,07 \\
\hline \multirow[t]{12}{*}{ C19 } & 36 & 2,17 & M19 & 26 & 3,10 \\
\hline & & & M20 & 21 & 2,64 \\
\hline & & & M21 & 21 & 3,08 \\
\hline & & & M22 & 21 & 2,00 \\
\hline & & & M23 & 26 & 3,01 \\
\hline & & & M24 & 26 & 2,80 \\
\hline & & & M25 & 20 & 2,74 \\
\hline & & & M26 & 11 & 2,58 \\
\hline & & & M27 & 13 & 2,42 \\
\hline & & & M28 & 14 & 2,88 \\
\hline & & & M29 & 14 & 2,71 \\
\hline & & & M30 & 15 & 2,58 \\
\hline
\end{tabular}

In interpreting the data we applied the rule that scores under or equal to 2,30 or above or equal to 3,70 reflect clear opinions of agreement or disagreement on these five point scales.

Further analysis of the original data per organization reveals such a distribution of the scores per item that in the vast majority of items normal distributions exist. 
Table 5 The correlation matrix*

\begin{tabular}{|c|c|c|c|c|c|c|c|c|c|c|c|c|c|c|c|c|c|}
\hline & & \multicolumn{3}{|c|}{$\begin{array}{l}\text { Process/results } \\
\text { oriented }\end{array}$} & \multicolumn{3}{|c|}{$\begin{array}{l}\text { Employee/job } \\
\text { oriented }\end{array}$} & \multicolumn{2}{|c|}{$\begin{array}{l}\text { Parochial/ } \\
\text { Professional }\end{array}$} & \multicolumn{2}{|c|}{$\begin{array}{l}\text { Open/ } \\
\text { closed }\end{array}$} & \multicolumn{3}{|c|}{$\begin{array}{l}\text { Loose/tight } \\
\text { control system }\end{array}$} & \multicolumn{3}{|c|}{$\mid \begin{array}{l}\text { Normative/ } \\
\text { Pragmatic }\end{array}$} \\
\hline & & $\mathrm{C3}$ & C8 & C18 & $\mathrm{C2}$ & C10 & C11 & $\mathrm{C5}$ & C16 & C6 & $\mathrm{C14}$ & $\mathrm{C4}$ & $\overline{C 7}$ & $\overline{C 13}$ & C1 & $\mathbf{C 1 5}$ & C17 \\
\hline \multirow{4}{*}{$\begin{array}{l}\text { General } \\
\text { items }\end{array}$} & M4 & -51 & & -61 & & -58 & -58 & -51 & & 63 & 44 & & 62 & & 70 & & -49 \\
\hline & M9 & -50 & & -64 & -46 & -62 & -46 & -57 & & 72 & 55 & -45 & 67 & & 70 & 44 & -57 \\
\hline & M17 & -56 & -55 & -73 & -49 & -74 & -62 & -59 & & 82 & 56 & -50 & 69 & & 73 & 67 & -53 \\
\hline & M28 & & & & & & & & & & & & & & -82 & & 85 \\
\hline \multirow{2}{*}{$\begin{array}{l}\text { Learning } \\
\text { organisation }\end{array}$} & M16 & -55 & & -73 & -54 & -69 & -66 & -48 & & 75 & 56 & -56 & 68 & & 76 & 59 & -56 \\
\hline & M29 & & & -70 & & & & & & 82 & & & 71 & & & 73 & \\
\hline \multirow[t]{4}{*}{ Customers } & M1 & & & -47 & & & & & & 47 & & & & 52 & & & \\
\hline & M11 & 53 & 56 & 67 & 46 & 68 & 55 & 70 & & -58 & & 56 & -48 & & -54 & -55 & 55 \\
\hline & M12 & & -47 & -51 & & -64 & -49 & & & 62 & & -47 & & & 51 & & -52 \\
\hline & M26 & & & & & & & & & 86 & 75 & & & & & & \\
\hline \multirow[t]{2}{*}{ Competitors } & M2 & -54 & -57 & -67 & -45 & -75 & -68 & -58 & -43 & 77 & & -51 & 62 & & 65 & 52 & -48 \\
\hline & M13 & & & 59 & & & & 53 & & & & & & & -67 & -63 & \\
\hline \multirow[t]{3}{*}{ Employees } & M15 & & & & & & & & & & & & & & & & -51 \\
\hline & M20 & & & -62 & & & -74 & & & 70 & & & 64 & & 60 & & -60 \\
\hline & M22 & & & & & & & & & & & & 61 & & & & \\
\hline \multirow{2}{*}{$\begin{array}{l}\text { Commit- } \\
\text { ment }\end{array}$} & M10 & & & & & & & & & 50 & 44 & & 51 & & 52 & & \\
\hline & M14 & -63 & & -54 & & -54 & -51 & -44 & & 64 & 58 & & 72 & & 70 & 53 & \\
\hline \multirow{4}{*}{$\begin{array}{l}\text { Coordination } \\
\& \text { dissemi- } \\
\text { nation of } \\
\text { information }\end{array}$} & M8 & 59 & & 72 & 53 & 68 & 64 & 61 & & -71 & -51 & & -68 & & -64 & -47 & 51 \\
\hline & M18 & 64 & & 77 & 66 & 71 & 73 & 66 & & $\begin{array}{l}-81 \\
\end{array}$ & -51 & 54 & -72 & & -61 & & 69 \\
\hline & M19 & & & -84 & & -73 & -62 & -69 & & 78 & & & 56 & & 73 & & -58 \\
\hline & M21 & & & -78 & & -74 & -62 & $\begin{array}{l}-57 \\
\end{array}$ & $\begin{array}{l}-59 \\
\end{array}$ & 78 & & & & & 64 & & \\
\hline \multirow{4}{*}{$\begin{array}{l}\text { New } \\
\text { product/ } \\
\text { service } \\
\text { development }\end{array}$} & M5 & -47 & & & & & & & & & & & & & & 53 & \\
\hline & M7 & 54 & & & & & & & & & & & & & & & \\
\hline & M23 & & & & -51 & -61 & & & & 59 & & & & & & & -51 \\
\hline & M24 & & -68 & -53 & & -55 & & & & 52 & & & & & & 52 & \\
\hline
\end{tabular}

* figures should be divided by 100 to get the simple Pearson correlation coefficient; all correlations significant at least at .05\% ** Only the lines and columns in which correlations were present, are shown in this table. So not shown are C9, C12 and C19 as well as M3, M6, M25, M27 and M30. 